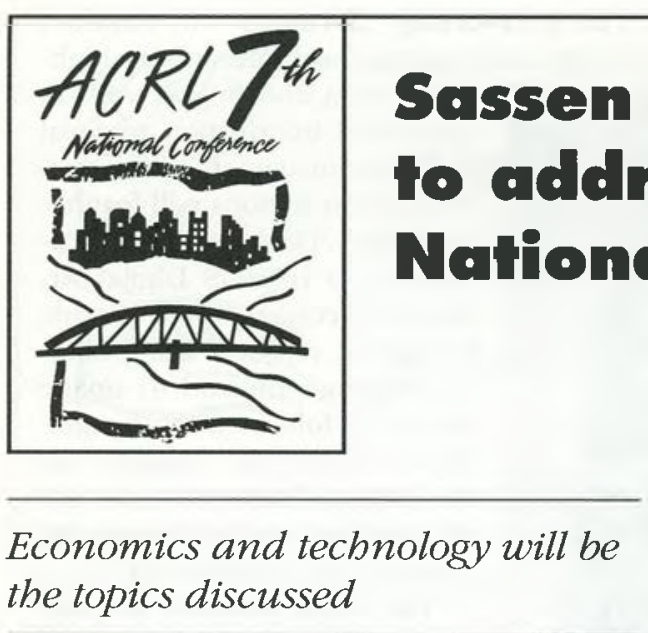

\section{the topics discussed}

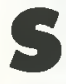

askia Sassen and John McChesney join Jennifer James and Ronald Takaki to complete the roster of theme speakers invited to address ACRL's 7th National Conference in Pittsburgh, March 29-April1, 1995. Don't miss this opportunity. Registration materials will be mailed to ACRL members this month.

\section{Saskia Sassen}

Saskia Sassen is professor of urban planning at Columbia University and a former chair of the Urban Planning Division. She will address "Society, Economics, and Politics" in her speech at the conference. Sassen's work is focused on international, regional, urban economic, and regulatory processes. She has conducted empirical research on these subjects and written about them in theoretical terms. She has written three books:

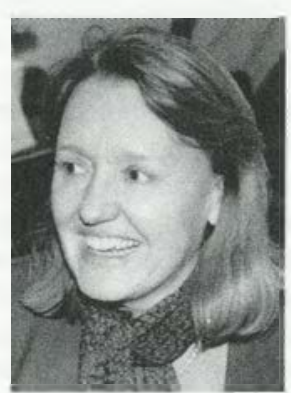

Saskia Sassen
The Mobility of Labor and Capital (1988), The Global City: New York London Tokyo (1991), and Cities in a World Economy (1994). She has also published extensively in academic journals and books. A past member of several research groups, among them the Japan-based Project on Economic Restructuring in the U.S. and Japan sponsored by the United Nations Centre on Regional Development, Sassen is currently part of the Immigration and Economic Sociology Project sponsored by the Russell Sage
Foundation, and the Comparative Urban Studies Project at the Woodrow Wilson Center.

Sassen received a Ph.D. from the University of Notre Dame and did post-doctoral work at the Universite de Poitres and Harvard University. She has given over 100 invited lectures in the U.S. and abroad.

\section{John McChesney}

John McChesney, a reporter and editor for $\mathrm{Na}$ tional Public Radio (NPR), will speak on "Technology and the Service-Centered Library." McChesney has been with NPR since 1979 and worked as a news and public affairs producer at local NPR stations before that. During his years at NPR McChesney has worn several hats, including that of national editor responsible for domestic news, and senior foreign editor. He has trav-

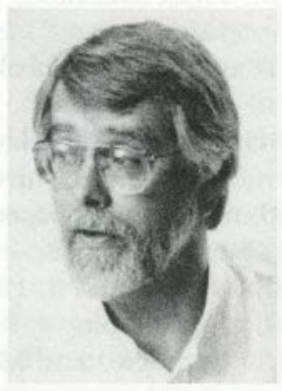

John McChesney eled extensively in Europe, Africa, the Middle East, Latin America, and Asia. He became involved in technology reporting as a result of his coverage of Japan and the issue of national competitiveness. For the past several years he has been reporting from Silicon Valley on various aspects of the information revolution--from microchips to multimedia. Recently his work has concentrated on the promise of broadband technologies--the so-called information superhighway. His reports are heard on All Things Considered and Moming Edition.

McChesney has won numerous awards for his work, including Dartmouth's Champion Award for business and economic reporting, and the Sidney Hilman Award for his series on manufacturing technology. 